\title{
Nascent Technology Entrepreneurship among Bulgarian STEM Students
}

\author{
Desislava Yordanova
}

\section{check for} updates

Citation: Yordanova, Desislava. 2021. Nascent Technology Entrepreneurship among Bulgarian STEM Students.

Administrative Sciences 11: 121

https://doi.org/10.3390/

admsci11040121

Received: 23 July 2021

Accepted: 2 October 2021

Published: 22 October 2021

Publisher's Note: MDPI stays neutral with regard to jurisdictional claims in published maps and institutional affiliations.

Copyright: (C) 2021 by the author. Licensee MDPI, Basel, Switzerland. This article is an open access article distributed under the terms and conditions of the Creative Commons Attribution (CC BY) license (https:// creativecommons.org/licenses/by/ $4.0 /)$.
Faculty of Economics and Business Administration, Sofia University "St. Kliment Ohridski", 1113 Sofia, Bulgaria; d_yordanova@feb.uni-sofia.bg

\begin{abstract}
Technology entrepreneurship may contribute significantly to economic development and innovation. Little research has investigated the role of the university in technology entrepreneurship among STEM (science, technology, engineering or mathematics) students. More research into the entrepreneurial intentions-behaviour link is needed. This paper aims to identify university-related factors that may contribute to the translation of technopreneurial implementation intentions into actions in a sample of 200 STEM students. The variables university research excellence and perceptions of business development support significantly influence the likelihood of nascent technopreneurial behaviour. This study contributes to a greater understanding of the technopreneurial process and the drivers of technopreneurial behaviour among STEM students. The results of this study may help to enhance nascent entrepreneurship among Bulgarian STEM students.
\end{abstract}

Keywords: nascent technology entrepreneurship; university; student entrepreneurship; STEM students

\section{Introduction}

It has been recognised that entrepreneurship might play a significant role in employment, growth of value-added and productivity and innovation (Van Praag and Versloot 2007). Technology entrepreneurship is a specific type of entrepreneurship with distinctive characteristics stemming from the combination of different concepts: entrepreneurship, technology and innovation (Petti 2009; Bailetti 2012; Nacu and Avasilcăi 2014). Several research gaps have been identified in the literature on technology entrepreneurship. Shane and Venkataraman (2003) call for more research into the context for technology entrepreneurship, the process of new technology venture creation and the drivers and reasons people create new technology ventures. Zhang et al. (2008) note the lack of studies combining individual and corporate technology entrepreneurship. Mosey et al. (2017) call for more research exploring the role of entrepreneurship education and university support measures for the generation of talent and the experience of individuals in relation to technology entrepreneurship. Mosey (2016) argues that the university is an ideal setting for research into technology entrepreneurship spanning different levels of analysis.

There has been significant research focusing on entrepreneurial intentions in the last decades (Liñán and Fayolle 2015). The premise of this literature is that entrepreneurial intentions provide an understanding of entrepreneurial behaviour without witnessing it (Krueger and Alan 1993), and models of intentions and their antecedents are a useful framework for studying entrepreneurial behaviour (Krueger et al. 2000). However, several authors highlight that the link between entrepreneurial intentions and behaviour might not be so straightforward. Krueger (2009) argue that there is no guarantee that a person's intentions for starting a business will be implemented. Krueger et al. (2000) stress that even when intentionality is present, the timing of the creation of the new venture might be relatively unplanned and even sudden. Shook et al. (2003, p. 383) argue that "it may be a relatively long or short time after intent develops before a new venture opportunity is even identified". Schlaegel and Koenig (2014) conclude that entrepreneurial 
intentions explain only $37 \%$ of the variance in actual entrepreneurial behaviour. It was acknowledged that the entrepreneurial intention-behaviour link needs further investigation (Fayolle and Liñán 2014).

Many students worldwide are in the process of starting their own business (i.e., nascent entrepreneurs) or are already owning and managing their own business (i.e., active entrepreneurs) (Sieger et al. 2018). However, most research into university entrepreneurship considers only data about spinoffs by faculty and staff and excludes data about new firm formation by students and graduates (Åstebro et al. 2012; Wright et al. 2019). Grimaldi et al. (2011) stress that student entrepreneurship had not received enough attention in the literature. Several recent studies call for more research into the role of the university in fostering student entrepreneurship (Wright et al. 2017; Alves et al. 2019; Wright et al. 2019), especially for STEM students.

Giving these research gaps, the purpose of this study is to identify university-related factors that contribute to the translation of technopreneurial implementation intentions into actions in a sample of Bulgarian STEM students. Fayolle and Liñán (2014) stress that students who exhibit entrepreneurial implementation intentions have a greater inclination to act on their intentions than students with entrepreneurial goal intentions. In this study, technology entrepreneurship is defined as the creation of a new business whose products or services depend largely on the application of scientific or technological knowledge (Allen 1992). Nascent technology entrepreneurship refers to startup effort aimed at establishing a new independent technology business, while nascent technology intrapreneurship involves technology entrepreneurial effort that is part of a job assignment (Delmar and Davidsson 2000). This research aims at testing the following hypotheses:

Hypotheses 1 (H1). Participation in entrepreneurship education positively influences the likelihood of nascent technology entrepreneurship or intrapreneurship among STEM students.

Hypotheses 2 (H2). Business development support provided by the university positively influences the likelihood of nascent technology entrepreneurship or intrapreneurship among STEM students.

Hypotheses 3 (H3). University research excellence increases the likelihood of nascent technology entrepreneurship or intrapreneurship among STEM students.

In order to test these hypotheses, this study uses a sample of 200 Bulgarian STEM students who either exhibit technopreneurial implementation intentions or are involved in nascent technology entrepreneurial or intrapreneurial activities. Taking into account the purpose of the study and the nature of the dependent variable, we employ binary logistic regression as a method for data analysis. Based on this analysis, this study discovers that university research excellence statistically positive affects the odds of nascent technology entrepreneurship/intrapreneurship among STEM students. On the contrary, surprisingly, business development support provided by the university has a statistically negative effect on technology entrepreneurship/intrapreneurship among STEM students. Finally, entrepreneurship education does not affect the likelihood of students' involvement in nascent technology entrepreneurship/intrapreneurship. These results will be discussed and explained in the final section of the paper.

The paper contributes to a greater understanding of the technopreneurial process and the drivers of technopreneurial behaviour among STEM students. The results of this study may help to enhance nascent technology entrepreneurship among Bulgarian STEM students.

\section{Hypotheses Development}

The literature on entrepreneurship education reveals that empirical evidence about the impact of entrepreneurship education on student entrepreneurship is mixed (Rideout and Gray 2013). The majority of the studies demonstrate that entrepreneurship education has a positive influence on students and graduates' involvement in nascent entrepreneurship. Using a quasi-experimental design, Rauch and Hulsink (2015) demonstrated that entrepreneurship education enhances subsequent nascent entrepreneurial 
behaviour. Kolvereid and Moen (1997) report that majoring in entrepreneurship significantly affects entrepreneurship in a longitudinal study. Charney et al. (2000) find that entrepreneurship education graduates are more likely to be instrumentally involved in a new business venture than other students. Menzies and Paradi (2002) report that taking an entrepreneurship course by undergraduate engineering students is associated with increases in business ownership, a longer time of owning a business and serial entrepreneurship. Several authors highlight the importance of practical-oriented entrepreneurship teaching models (Honig 2004; Rasmussen and Sørheim 2006; Pittaway and Cope 2007; Campos et al. 2017; Sansone et al. 2021). Practical rather than theoretical entrepreneurship education is positively associated with entrepreneurial behaviour (Sansone et al. 2021). Brown (1990) examines the influence of an entrepreneurship education programme on the entrepreneurial behaviour of undergraduate students using a pretest-posttest design. They report a high likelihood of participants in the programme surviving their first 30 months in business. Bergmann et al. (2016) find a significant effect of the entrepreneurship course participation rate on the number of university departments on nascent entrepreneurship. They conclude that the provision of entrepreneurship courses affects not only participating students but also their peers. In a longitudinal study in Columbia, Varela and Jiménez (2001) report that entrepreneurial activity is higher for graduates from universities that have offered students more entrepreneurship guidance and training. The participation of students in university entrepreneurship-related curricular programmes positively affects the scope of student startup activities (Morris et al. 2017). In their qualitative study, Games et al. (2019) report that entrepreneurship education has a positive contribution to nascent entrepreneurship in terms of motivation encouragement. Therefore, we suggest that:

Hypotheses 1 (H1). Participation in entrepreneurship education positively influences the likelihood of nascent technology entrepreneurship or intrapreneurship among STEM students.

Business development support by universities is defined as means and actions aimed at supporting startups at later stages of the entrepreneurial process (Kraaijenbrink et al. 2010). Business development support by universities may include financial support for students' startups (Kraaijenbrink et al. 2010). The university ecosystem facilitating student entrepreneurship involves diverse elements, including accelerators, incubators, grants and business plan competitions (Wright et al. 2017). Although technology transfer offices have not traditionally supported student entrepreneurship, this is beginning to change (Wright et al. 2017). Entrepreneurship support programmes can encourage entrepreneurial behaviour among students and can provide the necessary resources for startup, such as help from experts, know-how, training, counselling, financing, self-confidence, awareness, access to networks, etc. (Walter et al. 2013; Trivedi 2016).

Several studies reveal that the university environment is associated with entrepreneurial behaviour among students (Minola et al. 2016; Shirokova et al. 2016). Minola et al. (2016) demonstrate that students' progressive engagement in entrepreneurship is affected positively and significantly by university support for entrepreneurship. Shirokova et al. (2016) explore the link between entrepreneurial intention and behaviour in the context of student entrepreneurship. They find that the university environment affects the translation of entrepreneurial intentions into entrepreneurial actions. Arrighetti et al. (2016) show that perceptions of university support positively influence both the perceived likelihood of being an entrepreneur and the propensity to start a new venture among students. Boh et al. (2016) identify diverse university programmes and practices that enhance students' entrepreneurial efforts, including accelerator/incubator programmes, mentoring programmes, business plan competitions, etc. Drawing upon three case studies, Jansen et al. (2015) find that such entrepreneurship encouragement offerings may indeed effectively encourage student entrepreneurship. Students' involvement in entrepreneurship-related co-curricular activities organised by universities, such as mentoring, coaching, business plan competitions and workshops and networking, positively influences the scope of student startup activities (Morris et al. 2017). Boh et al. (2016) identify various university 
programmes and practices that enhance students' efforts for commercialising university technologies, such as project-based classes on technology commercialisation, mentoring programmes, accelerator/incubator programmes and business plan competitions. Thus, we argue that:

Hypotheses 2 (H2). Business development support provided by the university positively influences the likelihood of nascent technology entrepreneurship or intrapreneurship among STEM students.

Empirical research demonstrates that the research excellence of universities is associated with entrepreneurial activity. Scientific research may provide important sources of technological opportunities (D'Este et al. 2012). Empirical evidence reveals that scientific research is associated with patenting (Azoulay et al. 2007; Van Looy et al. 2011). Research-intensive universities create entrepreneurial opportunities based on new knowledge (Audretsch and Lehmann 2005; Acs et al. 2013; Fritsch and Aamoucke 2013; Ghio et al. 2015; Ghio et al. 2019). Bailetti (2012) argues that the stock of university-based knowledge affects the level of student entrepreneurship at a university. New knowledge generated by research institutions has a significant role for younger and well-educated founders of high-technology ventures (Amoroso et al. 2018) and for the growth of academic spinoffs (Barbosa and Faria 2020). Public research and education have a strong, positive effect on new business creation in innovative industries (Fritsch and Aamoucke 2013). New knowledge generated by high-quality universities is associated with the creation of knowledge-intensive firms (Bonaccorsi et al. 2014). Universities with higher levels of research productivity tend to develop more spinoffs (Van Looy et al. 2011). Research excellence of the university positively affects the discovery of technological opportunities (D'Este et al. 2012) and the likelihood of new technology venture creation among students and new graduates (Beyhan and Findik 2018). Boh et al. (2016) find that students are involved in the commercialisation of technologies generated from universities research labs. Hayter et al. (2016) find that the entrepreneurial role of students is related to knowledge production. More research-oriented universities may be more likely to provide students with superior knowledge and skills to create and commercialise complex ideas (Walter et al. 2013). Therefore, we posit that:

Hypotheses 3 (H3). University research excellence increases the likelihood of nascent technology entrepreneurship or intrapreneurship among STEM students.

Table 1 presents previous empirical studies examining the impact of university-related factors on students and graduates' involvement in nascent entrepreneurship.

Table 1. University factors affecting students and graduates' involvement in nascent entrepreneurship.

\begin{tabular}{ll}
\hline \multicolumn{1}{c}{ University Factors } & \multicolumn{1}{c}{ Empirical Evidence } \\
\hline $\begin{array}{l}\text { Entrepreneurship } \\
\text { education }\end{array}$ & $\begin{array}{l}\text { Kolvereid and Moen (1997); Charney et al. (2000); Bergmann et al. } \\
\text { (2016); Morris et al. (2017); Games et al. (2019); Onjewu et al. (2021) }\end{array}$ \\
\hline $\begin{array}{l}\text { University support for } \\
\text { entrepreneurship }\end{array}$ & $\begin{array}{l}\text { Boh et al. (2016); Minola et al. (2016); Shirokova et al. (2016); } \\
\text { Morris et al. (2017); Wright et al. (2017) }\end{array}$ \\
\hline Research excellence & Boh et al. (2016); Beyhan and Findik (2018) \\
\hline Source: Own elaboration. &
\end{tabular}

\section{Research Methodology}

\subsection{Data Collection and Sample}

In order to identify university-related factors that may contribute to the translation of technopreneurial implementation intentions into actions, we used a sample of 200 STEM students who either exhibit technopreneurial implementation intentions (149 STEM students) or are involved in nascent technology entrepreneurial or intrapreneurial activities (51 STEM students). The sample was extracted from a database about technology entrepreneurship among Bulgarian STEM students. The data were collected through a survey 
about technology entrepreneurship among Bulgarian STEM students in 15 Bulgarian universities conducted in the academic year 2015/2016. Students in STEM majors have a greater potential to become technology entrepreneurs compared with other students (Souitaris et al. 2007). All 28 Bulgarian higher education institutions providing STEM undergraduate and graduate programmes were contacted and invited to participate in the survey. The total number of STEM students in these higher education institutions was 72,053 (National Statistical Institute 2016). A consent to participate in the survey was obtained only from 15 universities, while the other 13 universities refused to participate or did not respond to the invitation. The total number of STEM students in the participating universities was 50,266.

The questionnaire of the study was created by the author based on previous research on the role of the university in student entrepreneurship (Kolvereid and Moen 1997; Varela and Jiménez 2001; Souitaris et al. 2007; Kraaijenbrink et al. 2010; D’Este et al. 2012; Walter et al. 2013). It contains various questions related to the demographic characteristics of respondents, entrepreneurial intentions and behaviour, participation in entrepreneurship education and perceptions of university factors. A pilot study was conducted among 15 students (8 males and 7 females) to pre-test the initial version of the questionnaire. Due to comments from some students, minor changes were introduced in some questions. With the approval and cooperation of rectors, deans, department heads and lecturers in 15 Bulgarian universities, a questionnaire was distributed during class sessions. Students were informed that participation in the survey was voluntary, and questionnaires were only for research purposes. In the instructions to respondents regarding the filling-in procedure, they were advised that the instrument should be completed anonymously and that it was important to answer all questions. The author was present during the data collection on most occasions to secure a high response rate, to monitor respondents while they were answering the questionnaire and to be able to answer further questions from respondents. The STEM students participating in the survey were not randomly selected $(n=1061)$. Therefore, the sample is not statistically representative of the population of Bulgarian STEM students. However, it may help to preliminarily understand how Bulgarian universities may foster student technology entrepreneurship.

The sample of this study is composed of 200 STEM students who either exhibit technopreneurial implementation intentions (149 STEM students) or are involved in nascent technology entrepreneurial or intrapreneurial activities (51 STEM students). Some students have a part-time or full-time job, and they may be involved in establishing a new technology business for their employer as part of their job (Delmar and Davidsson 2000). The STEM students with technopreneurial implementation intentions reported that they think they will start a technology business (Krueger 1993), and they already know at least two of where, when and how aspects of starting a technology business (Gollwitzer and Brandstätter 1997; Orbell et al. 1997; Sheeran and Orbell 1999). The STEM students involved in nascent technology entrepreneurial activities declared that alone or with others are currently trying to create a new independent technology business (Delmar and Davidsson 2000). The STEM students involved in nascent technology intrapreneurial activities stated that alone or with others are currently trying to start a new technology business for his/her employer as part of his/her job (Delmar and Davidsson 2000).

Most respondents are enrolled in universities located in Sofia, the capital of Bulgaria $(62 \%)$. Bachelor students represent $75 \%$ of the respondents in the sample, while only $25 \%$ of the respondents are master's students. More than $81 \%$ of the respondents are full-time students, while the rest of the respondents are part-time students. About $71 \%$ of the respondent are younger than 24 years. The great majority of the respondents are male students $(65.5 \%)$. Female students account for less than $35 \%$ of the sample. Only $43 \%$ of the respondents studied a compulsory or elective entrepreneurship course. 


\subsection{Definition of the Variables}

The dependent variable nascent technology entrepreneurship/intrapreneurship (NASC_ENTR) is binary and takes a value of 1 if the respondent alone or with others are currently trying to start a new independent technology business or a new technology business for his/her employer as part of his/her job (Delmar and Davidsson 2000).

The study uses participation in entrepreneurship education, perceptions of business development support provided by the university and research excellence as independent variables. The dummy variable participation in entrepreneurship education (ENT_EDU) takes a value of 1 if the respondent studied a compulsory or elective entrepreneurship course within the university and a value of 0 if not. The variable perceptions of business development support provided by the university (BUS_DEV) is measured with a 3-item 7-point Likert scale developed by Kraaijenbrink et al. (2010), which reveals students' perceptions of the support for business development by the university beyond teaching. The variable research excellence (RES_EXC) is measured with the value of the H-index of the university in the scientific field of study of the respondent in the scientific database Scopus.

The study controls for differences in gender, social network support, willingness to take risks among respondents and industry guest lecturers. The dichotomous variable gender (GENDER) takes a value of 1 if the respondent is male and a value of 0 if she is female. The dichotomous variable social network support (SOC_NET_SUP) takes a value of 1 if the respondent can rely on support from her/his social network in case she/he becomes an entrepreneur and a value of 0 if otherwise (Walter et al. 2013). The variable willingness to take risks (RISK) is measured with a 4-item 7-point Likert scale adopted from Gomez-Mejia and Balkin (1989); the Cronbach's alpha of this scale is 0.763 . The variable industry guest lecturers (GUEST_LECTURERS) is measured with a 2-item 7-point Likert scale and indicates students' perceptions of the frequency of lectures and presentations held by industry partners at the university (Walter et al. 2013); the Cronbach's alpha of that scale is 0.933 . We wanted to include an additional control variable indicating whether the respondent's university is in Sofia. However, this variable is highly correlated with the variable RES_EXC $(r=0.610)$ and, therefore, was not used in the analyses. Table 2 presents the definition of the variables used in the study.

Table 2. Definition of the variables used in the study.

\begin{tabular}{|c|c|}
\hline Variable & Description \\
\hline NASC_ENTR & $\begin{array}{l}\text { Dummy variable that is equal to } 1 \text { if the respondent alone or with others are currently trying to start a new } \\
\text { independent technology business or a new technology business for his/her employer as part of his/her } \\
\text { job, and a value of } 0 \text { if otherwise (Delmar and Davidsson 2000). }\end{array}$ \\
\hline ENT_EDU & $\begin{array}{l}\text { Dummy variable that is equal to } 1 \text { if the respondent studied a compulsory or elective entrepreneurship } \\
\text { course within the university, and a value of } 0 \text { if otherwise. }\end{array}$ \\
\hline BUS_DEV & $\begin{array}{l}\text { Respondents' perceptions of the support for business development by the university beyond teaching } \\
\text { measured with a 3-item 7-point Likert scale developed by Kraaijenbrink et al. (2010). }\end{array}$ \\
\hline RES_EXC & H-index of the university in the scientific field of study of the respondent in the scientific database Scopus. \\
\hline GENDER & Dummy variable that is equal to 1 if the respondent is male, and a value of 0 if otherwise. \\
\hline SOC_NET_SUP & $\begin{array}{l}\text { Dummy variable that is equal to } 1 \text { if the respondent can rely on support from his/her social network in } \\
\text { case s/he becomes an entrepreneur, and a value of } 0 \text { if otherwise. }\end{array}$ \\
\hline RISK & $\begin{array}{l}\text { Respondents' willingness to take risks measured with a 4-item 7-point Likert scale adopted from } \\
\text { Gomez-Mejia and Balkin (1989). }\end{array}$ \\
\hline GUEST_LECTURERS & $\begin{array}{l}\text { Respondents' perceptions of the frequency of lectures and presentations held by industry partners at the } \\
\text { university measured with a 2-item 7-point Likert scale (Walter et al. 2013). }\end{array}$ \\
\hline
\end{tabular}


The study uses binary logistic regression to examine the effects of independent variables on the binary dependent variable NASC_ENTR. It is performed with the statistical package SPSS, version 25.

\section{Results}

Correlations between independent and control variables used in the study are presented in Table 3. Female students in our sample exhibit more positive perceptions of the support for business development by the university beyond teaching than male students. Male students are less likely to be enrolled in an entrepreneurship course and less likely to perceive social network support for entrepreneurship compared to female students. Students in universities with better research exhibit less positive perceptions of the support for business development by the university beyond teaching than other students. The correlations between the two independent variables do not exceed 0.32 .

Table 3. Correlation matrix.

\begin{tabular}{|c|c|c|c|c|c|c|c|}
\hline Variable & 1 & 2 & 3 & 4 & 5 & 6 & 7 \\
\hline 1. NASC_ENTR & 1 & & & & & & \\
\hline 2. ENT_EDU & -0.062 & 1 & & & & & \\
\hline 3. BUS_DEV & $-0.250 * *$ & $0.163 *$ & 1 & & & & \\
\hline 4. RES_EXC & $0.190 * *$ & -0.120 & $-0.183^{* *}$ & 1 & & & \\
\hline 5. GENDER & $0.183^{* *}$ & $-0.312 * *$ & -0.178 * & 0.054 & 1 & & \\
\hline 6. SOC_NET_SUP & -0.064 & 0.096 & 0.061 & 0.038 & $-0.142 *$ & 1 & \\
\hline 7. RISK & 0.029 & -0.009 & 0.118 & 0.032 & 0.041 & 0.034 & 1 \\
\hline 8. GUEST_LECTURERS & -0.117 & $0.235 * *$ & $0.274^{* *}$ & 0.007 & -0.125 & 0.023 & 0.079 \\
\hline
\end{tabular}

${ }^{*}$ Correlation is significant at 0.01 . ${ }^{* *}$ Correlation is significant at 0.05 .

Table 4 reports the descriptive statistics of the variables used in the study. Almost $80 \%$ of the respondents think that they can rely on support from their social network in case they become entrepreneurs. The high standard deviation of the variable RES_EXC indicates that some universities exhibit low research orientation in some scientific fields.

Table 4. Descriptive statistics of the variables used in the study.

\begin{tabular}{lccccc}
\hline \multicolumn{1}{c}{ Variable } & Mean & Median & SD & Min & Max \\
\hline 1. NASC_ENTR & 0.26 & 0 & 0.44 & 0 & 1 \\
2. ENT_EDU & 0.43 & 0 & 0.50 & 0 & 1 \\
3. BUS_DEV & 3.15 & 3 & 2.15 & 1 & 7 \\
4. RES_EXC & 8.56 & 5 & 5.62 & 2 & 22 \\
5. GENDER & 0.65 & 1 & 0.48 & 0 & 1 \\
6. SOC_NET_SUP & 0.79 & 1 & 0.41 & 0 & 1 \\
7. RISK & 3.41 & 3.25 & 1.38 & 1 & 7 \\
8. GUEST_LECTURERS & 3.04 & 3 & 1.85 & 1 & 7 \\
\hline
\end{tabular}

Four binary logistic regression models are estimated to assess the robustness of the results (Table 5). Model 1 includes the independent variables only. The second model adds GENDER as a control variable. Model 5 additionally has the control variable SOC_NET_SUP. The fourth model adds the control variable RISK, and the fifth model controls additionally for GUEST_LECTURERS. A Chi-square statistic is applied to determine the significance level of the models. The estimated models predict the likelihood of nascent technology entrepreneurship/intrapreneurship among students at a $99 \%$ confidence level. The variance inflation factor (VIF) values for the variables in the four regressions are within the acceptable limits (less than 1.2) and, therefore, do not indicate multicollinearity problems (Hair et al. 1995). The overall predictive ability of the models to correctly classify students by their involvement in nascent technology entrepreneurship/intrapreneurship exceeds $76 \%$. Two independent variables significantly affect the odds of nascent technol- 
ogy entrepreneurship/intrapreneurship in all models. The variable RES_EXC positively influences the odds of nascent technology entrepreneurship/intrapreneurship $(p<0.05)$. Students in research-oriented universities are more likely to be involved in nascent technology entrepreneurship/intrapreneurship than students in other universities $(p<0.05)$. The variable BUS_DEV negatively influences the likelihood of nascent technology entrepreneurship/intrapreneurship $(p<0.01)$. The coefficient of the variable ENT_EDU is not significant $(p>0.05)$. Participation in entrepreneurship education is not related to the likelihood of involvement in nascent technology entrepreneurship/intrapreneurship. Only the control variable GENDER exerts a significant influence on the likelihood of nascent technology entrepreneurship/intrapreneurship $(p<0.1)$. Male students are more likely to be involved in nascent technology entrepreneurship/intrapreneurship than female students in our sample. The odds of nascent technology entrepreneurship/intrapreneurship are not associated with the control variables SOC_NET_SUP, RISK and GUEST_LECTURERS.

Table 5. Logit regression. Dependent variable: nascent technology entrepreneurship/intrapreneurship.

\begin{tabular}{|c|c|c|c|c|c|}
\hline & Model 1 & Model 2 & Model 3 & Model 4 & Model 5 \\
\hline Variable & B (S.E.) & B (S.E.) & B (S.E.) & B (S.E.) & B (S.E.) \\
\hline ENT_EDU & $\begin{array}{l}-0.123 \\
(0.356)\end{array}$ & $\begin{array}{c}0.101 \\
(0.376)\end{array}$ & $\begin{array}{c}0.111 \\
(0.377)\end{array}$ & $\begin{array}{c}0.107 \\
(0.377)\end{array}$ & $\begin{array}{c}0.178 \\
(0.384)\end{array}$ \\
\hline BUS_DEV & $\begin{array}{c}-0.362 * * * \\
(0.118)\end{array}$ & $\begin{array}{c}-0.344^{* * *} \\
(0.120)\end{array}$ & $\begin{array}{c}-0.342^{* * *} \\
(0.120)\end{array}$ & $\begin{array}{c}-0.347^{* * *} \\
(0.121)\end{array}$ & $\begin{array}{c}-0.323 \text { *** } \\
(0.124)\end{array}$ \\
\hline RES_EXC & $\begin{array}{l}0.060 * * \\
(0.030)\end{array}$ & $\begin{array}{l}0.059 * \\
(0.030)\end{array}$ & $\begin{array}{l}0.060 * * \\
(0.030)\end{array}$ & $\begin{array}{c}0.059 * \\
(0.30)\end{array}$ & $\begin{array}{l}0.063 \text { ** } \\
(0.031)\end{array}$ \\
\hline GENDER & & $\begin{array}{l}0.828 * \\
(0.422)\end{array}$ & $\begin{array}{l}0.799 * \\
(0.425)\end{array}$ & $\begin{array}{c}0.787 \\
(0.425) \\
\end{array}$ & $\begin{array}{l}0.784 \text { * } \\
(0.426)\end{array}$ \\
\hline SOC_NET_SUP & & & $\begin{array}{l}-0.270 \\
(0.407)\end{array}$ & $\begin{array}{l}-0.271 \\
(0.407)\end{array}$ & $\begin{array}{l}-0.285 \\
(0.409)\end{array}$ \\
\hline RISK & & & & $0.060(0.131)$ & $\begin{array}{c}0.064 \\
(0.131) \\
\end{array}$ \\
\hline GUEST_LECTURERS & & & & & $\begin{array}{l}-0.103 \\
(0.104)\end{array}$ \\
\hline Constant & $\begin{array}{l}-0.585 \\
(0.484)\end{array}$ & $\begin{array}{c}-1.298 * \\
(0.616)\end{array}$ & $\begin{array}{l}-1.091 \\
(0.688) \\
\end{array}$ & $\begin{array}{l}-1.257 \\
(0.779)\end{array}$ & $\begin{array}{l}-1.093 \\
(0.794)\end{array}$ \\
\hline Observations & 200 & 200 & 200 & 200 & 200 \\
\hline Model Chi-square & $18.190^{* * *}$ & $22.305^{* * *}$ & $22.747^{* * *}$ & $22.951^{* * *}$ & $23.954^{* * *}$ \\
\hline-2 Log likelihood & 206.267 & 202.052 & 201.616 & 201.406 & 200.403 \\
\hline Nagelkerke R Square & 0.129 & 0.157 & 0.160 & 0.161 & 0.168 \\
\hline
\end{tabular}

The table reports the logit estimates from several regression models. Model 1 is the baseline model. Model 2 adds GENDER. Model 3 adds SOC_NET_SUP. Model 4 adds RISK. Model 5 additionally controls for GUEST_LECTURERS. Standard errors are in parentheses. ${ }^{*} p<0.1$, ${ }^{* *} p<0.05,{ }^{* * *} p<0.01$.

\section{Discussion}

Fostering technology entrepreneurship is an important way to enhance wealth, value creation and economic growth (Bailetti 2012). Although there is a growing literature on technology entrepreneurship (Ratinho et al. 2015), the factors that foster technopreneurial behaviour are not clearly understood. This study aims to identify university-related factors that contribute to the translation of technopreneurial implementation intentions into actions in a sample of Bulgarian STEM students. Our study is based on the premise that university-related factors encourage the involvement of STEM students in nascent technology entrepreneurship/intrapreneurship after controlling for individual differences. The findings of the present study support previous empirical evidence that universities have some influence on students' entrepreneurial activity (Bergmann et al. 2016). 
We find no significant relationship between the odds of nascent technology entrepreneurship/intrapreneurship and the participation in entrepreneurship education. Hypothesis $\mathrm{H} 1$ can be rejected. These results contradict previous evidence about a link between entrepreneurship education and entrepreneurial behaviour (Kolvereid and Moen 1997; Charney et al. 2000; Varela and Jiménez 2001; Menzies and Paradi 2002; Games et al. 2019; Onjewu et al. 2021). Although entrepreneurship education positively affects the entrepreneurial intentions of STEM students (Souitaris et al. 2007), it is not able to foster nascent technology entrepreneurship/intrapreneurship among these students. One possible explanation about the lack of significant influence of entrepreneurship education on the likelihood of nascent technology entrepreneurship/intrapreneurship is that the content and teaching methods used in entrepreneurship courses in the studied universities may not be relevant to the specific needs of STEM students or may be too theoretical. Indeed, previous research demonstrates that some methods in entrepreneurship education, such as guest speakers, are not able to stimulate nascent technology entrepreneurship (Onjewu et al. 2021). Some classroom activities that are common in entrepreneurship education have a negative effect on students' entrepreneurial self-efficacy (Kassean et al. 2015). Several authors highlight the importance of practical-oriented entrepreneurship teaching models (Honig 2004; Rasmussen and Sørheim 2006; Pittaway and Cope 2007; Campos et al. 2017; Sansone et al. 2021). Sansone et al. (2021) demonstrate that practical rather than theoretical entrepreneurship education is positively related to the creation of academic spinoffs. Action-based entrepreneurship education focuses on new venture creation by students (Rasmussen and Sørheim 2006). Practical-oriented teaching models are associated with increased students' perceptions of their entrepreneurial skills (Fiore et al. 2019). Onjewu et al. (2021) demonstrate that active learning methods in entrepreneurship education such as simulations and workshops can stimulate nascent technology entrepreneurship.

Contrary to our hypothesis (H2), business development support provided by the university has a significant negative impact on the likelihood of nascent technology entrepreneurship/intrapreneurship. Hypothesis $\mathrm{H} 2$ can be rejected. This could be explained with the use of a perceptual measure of the support for business development by the university beyond teaching (Kraaijenbrink et al. 2010). It seems that STEM students engaged in nascent technology entrepreneurship/intrapreneurship tend to perceive lower business development support provided by the university than other students. This may be due to higher needs and expectations of business development support by the university among these students. Indeed, previous empirical evidence suggests that expectations and needs for support become more precise and focused on implemental issues as individuals progress through the various stages of the entrepreneurial process (Delanoë-Gueguen and Fayolle 2019). These results are not surprising in light of the absence of a clearly defined role for higher education institutions in Bulgaria in promoting entrepreneurship and innovation (OECD 2014). Bulgarian higher education institutions exhibit a narrow understanding of the concept of an innovative and entrepreneurial university and do not recognise entrepreneurship promotion as a strategic goal (OECD 2014). Bulgarian universities lack efficient coordination mechanisms for entrepreneurship promotion, such as entrepreneurship centres, technology transfer centres, incubators, etc. (OECD 2014). The paper shows that the research excellence of the university tends to significantly increase the likelihood of students' involvement in nascent technology entrepreneurship/intrapreneurship. Hypothesis $\mathrm{H} 3$ was confirmed. It seems that the scientific environments of universities have a direct impact on their students (Beyhan and Findik 2018). These results are in line with recent empirical evidence about the role of scientific research for the discovery of technological opportunities (D'Este et al. 2012), entrepreneurship in innovative industries (Fritsch and Aamoucke 2013), creation of knowledge-intensive firms (Bonaccorsi et al. 2014) and technology entrepreneurship among students and recent graduates (Beyhan and Findik 2018). They support the previous findings of the positive influence of high-quality universities on knowledge-intensive entrepreneurship (Bonaccorsi et al. 2014). In accor- 
dance with the literature (e.g., D'Este and Perkmann 2011; Beyhan and Findik 2018), our results indicate that research is a traditional university function that is an important factor for the creation of entrepreneurial universities.

\section{Conclusions}

The research into nascent technology entrepreneurship and intrapreneurship is important because it can generate valuable insights about technopreneurial process and its determinants (Davidsson 2006). Research on technopreneurial processes can provide an understanding of how to unleash technopreneurial potential and can help to encourage technopreneurial activity among STEM students. This paper is among the first to investigate the influence of university-related factors for the transformation of technopreneurial implementation intentions into actions among STEM students. Our findings demonstrate that universities may play an important role in fostering nascent entrepreneurship/intrapreneurship among STEM students. The likelihood of nascent technology entrepreneurship/intrapreneurship among STEM students is positively associated with university research excellence and negatively associated with business development support provided by the university. Entrepreneurship education has no effect on the likelihood of students' involvement in nascent technology entrepreneurship/intrapreneurship.

Several limitations of the study should be acknowledged before we discuss possible directions for future research. Our hypotheses are built on previous empirical findings and do not refer to any theory. Since the sample used in this study is not representative of the population of STEM students who exhibit technopreneurial implementation intentions or nascent technology entrepreneurial or intrapreneurial behaviour, the findings should be interpreted with caution. The sample is comprised only of Bulgarian STEM students and, therefore, the findings may not be applicable in other countries. Due to the self-reported nature of the study, errors and cognitive biases cannot be ruled out. The author did not perform interviews with students and academic staff that could have provided relevant information to understand the results of the study. Furthermore, differences in the nature of the entrepreneurship courses between participating universities are not considered.

Future research on nascent entrepreneurship among STEM students can take several directions. It will be useful to apply theories such as the theory of planned behaviour (Ajzen 1991) in future studies exploring the influence of university-related factors on nascent entrepreneurship. Future research based on representative samples from different countries should replicate our study. Future studies should investigate more thoroughly the role of content and teaching methods used in entrepreneurship courses for nascent technology entrepreneurship/intrapreneurship among STEM students. It is important to investigate the specific needs and expectations for support of STEM students involved in nascent entrepreneurship/intrapreneurship. Future research should identify the reasons for the lower likelihood of nascent technology entrepreneurship/intrapreneurship among female STEM students in comparison to males STEM students. Furthermore, the study calls for longitudinal research to identify causal links between the likelihood of nascent technology entrepreneurship/intrapreneurship among STEM students and universityrelated factors. Future research should also explore the role of universities in spatial variations of new and small companies (Goetz and Rupasingha 2009; Rupasingha and Contreras 2014). The adoption of mixed methods can help researchers to better understand and test their results in future studies.

The results of this study have several practical implications for policymakers and universities. The findings that participation in entrepreneurship education does not influence the odds of nascent technology entrepreneurship/intrapreneurship among STEM students implies that there is a need to revise the content and teaching methods used in entrepreneurship courses for STEM students in Bulgarian universities. For example, Secundo et al. (2020) emphasise the need for new entrepreneurial education approaches such as project-based and action-based approaches. Practical entrepreneurship education may enhance the creation of academic spinoffs (Sansone et al. 2021). In addition, 
STEM students should be encouraged by their professors and mentors to consider technology entrepreneurship as a potential career option. Policymakers and university managers should be aware of the important role of university research excellence for nascent technology entrepreneurship/intrapreneurship among STEM students. The research orientation of Bulgarian universities may play an important role in their entrepreneurial transformation. More specific and targeted university support for business development should be provided to STEM students engaged in nascent technology entrepreneurship/intrapreneurship because they have different expectations and needs than students intending to start a business. Bulgarian universities should increase and improve the structures for entrepreneurship promotion and support, such as business incubators, business accelerators, entrepreneurship centres, science parks, technology transfer offices, co-working spaces, student-led entrepreneurial organisations, etc. Specific policies and measures for decreasing specific barriers to entrepreneurship stimulating nascent technology entrepreneurship/intrapreneurship among female STEM students are needed. High-technology entrepreneurship is more likely to contribute to innovation and growth than all new and small businesses and, therefore, policies and programmes should focus specifically on this type of entrepreneurship (Low and Isserman 2015).

Funding: This research was funded by the Scientific Research Fund of Sofia University "St. Kliment Ohridski" (contract N 80-10-132/26.03.2021).

Institutional Review Board Statement: Not applicable.

Informed Consent Statement: Informed consent was obtained from all subjects involved in the study.

Data Availability Statement: Not applicable.

Conflicts of Interest: The authors declare no conflict of interest.

\section{References}

Acs, Zoltan, David Audretsch, and Erik Lehmann. 2013. The knowledge spillover theory of entrepreneurship. Small Business Economics 41: 757-74. [CrossRef]

Ajzen, Icek. 1991. The theory of planned behavior. Organizational Behavior and Human Decision Processes 50: 179-211. [CrossRef]

Allen, John. 1992. Starting a Technology Business. London: Pitman.

Alves, André Cherubini, Bruno Fischer, Paola Rücker Schaeffer, and Sérgio Queiroz. 2019. Determinants of student entrepreneurship: An assessment on higher education institutions in Brazil. Innovation \& Management Review 16: 96-117. [CrossRef]

Amoroso, Sara, David Audretsch, and Albert Link. 2018. Sources of knowledge used by entrepreneurial firms in the European high-tech sector. Eurasian Business Review 8: 55-70. [CrossRef]

Arrighetti, Alessandro, Fabio Landini, Luca Caricati, and Nadia Monacelli. 2016. Entrepreneurial intention in the time of crisis: A field study. International Journal of Entrepreneurial Behavior and Research 22: 835-59. [CrossRef]

Åstebro, Thomas, Navid Bazzazian, and Serguey Braguinsky. 2012. Startups by recent graduates and their faculty: Implications for university entrepreneurship policy. Research Policy 41: 663-77. [CrossRef]

Audretsch, David, and Erik Lehmann. 2005. Does the knowledge spillover theory of entrepreneurship hold for regions? Research Policy 34: 1191-202. [CrossRef]

Azoulay, Pierre, Waverly Ding, and Toby Stuart. 2007. The determinants of faculty patenting behavior: Demographics or opportunities? Journal of Economic Behavior E Organization 63: 599-623. [CrossRef]

Bailetti, Tony. 2012. Technology entrepreneurship: Overview, definition, and distinctive aspects. Technology Innovation Management Review 2: 5-12. [CrossRef]

Barbosa, Natália, and Ana Paula Faria. 2020. The effect of entrepreneurial origin on firms' performance: The case of Portuguese academic spinoffs. Industrial and Corporate Change 29: 25-42. [CrossRef]

Bergmann, Heiko, Christian Hundt, and Rolf Sternberg. 2016. What makes student entrepreneurs? On the relevance (and irrelevance) of the university and the regional context for student start-ups. Small Business Economics 47: 53-76. [CrossRef]

Beyhan, Berna, and Derya Findik. 2018. Student and graduate entrepreneurship: Ambidextrous universities create more nascent entrepreneurs. The Journal of Technology Transfer 43: 1346-74. [CrossRef]

Boh, Wai Fong, Uzi De-Haan, and Robert Strom. 2016. University technology transfer through entrepreneurship: Faculty and students in spinoffs. The Journal of Technology Transfer 41: 661-69. [CrossRef]

Bonaccorsi, Andrea, Massimo Colombo, Massimiliano Guerini, and Cristina Rossi-Lamastra. 2014. The impact of local and external university knowledge on the creation of knowledge-intensive firms: Evidence from the Italian case. Small Business Economics 43: 261-87. [CrossRef] 
Brown, Robert. 1990. Encouraging enterprise: Britain's graduate enterprise program. Journal of Small Business Management $28: 71-77$. Campos, Francisco, Michael Frese, Markus Goldstein, Leonardo Iacovone, Hillary Johnson, David McKenzie, and Mona Mensmann. 2017. Teaching personal initiative beats traditional training in boosting small business in West Africa. Science 357: 1287-90. [CrossRef] [PubMed]

Charney, Alberta, Gary Libecap, and Karl Eller Center. 2000. The Impact of Entrepreneurship Education: An Evaluation of the Berger Entrepreneurship Program at the University of Arizona 1985-1999. Report Prepared for the Kauffman Center for Entrepreneurial Leadership. Kansas City: The Ewing Marion Kauffman Foundation.

Delmar, Frederic, and Per Davidsson. 2000. Where do they come from? Prevalence and characteristics of nascent entrepreneurs. Entrepreneurship \& regional development 12: 1-23.

D'Este, Pablo, and Markus Perkmann. 2011. Why do academics engage with industry? The entrepreneurial university and individual motivations. The Journal of Technology Transfer 36: 316-39. [CrossRef]

D’Este, Pablo, Surya Mahdi, Andy Neely, and Francesco Rentocchini. 2012. Inventors and entrepreneurs in academia: What types of skills and experience matter? Technovation 32: 293-303. [CrossRef]

Davidsson, Per. 2006. Nascent Entrepreneurship: Empirical Studies and Developments. Foundations and Trends in Entrepreneurship 2: 1-76. [CrossRef]

Delanoë-Gueguen, Servane, and Alain Fayolle. 2019. Crossing the entrepreneurial Rubicon: A longitudinal investigation. Journal of Small Business Management 57: 1044-65. [CrossRef]

Fayolle, Alain, and Francisco Liñán. 2014. The future of research on entrepreneurial intentions. Journal of Business Research 67: 663-66. [CrossRef]

Fiore, Eleonora, Guiliano Sansone, and Emilio Paolucci. 2019. Entrepreneurship education in a multidisciplinary environment: Evidence from an entrepreneurship Programme held in Turin. Administrative Sciences 9: 28. [CrossRef]

Fritsch, Michael, and Ronney Aamoucke. 2013. Regional public research, higher education, and innovative start-ups: An empirical investigation. Small Business Economics 41: 865-85. [CrossRef]

Games, Donard, Dessy Kurnia Sari, and Venny Darlis. 2019. Entrepreneurship Education and Nascent Entrepreneurship: A Qualitative Study. AMAR (Andalas Management Review) 3: 28-43. [CrossRef]

Ghio, Niccolò, Massimiliano Guerini, and Cristina Rossi-Lamastra. 2019. The creation of high-tech ventures in entrepreneurial ecosystems: Exploring the interactions among university knowledge, cooperative banks, and individual attitudes. Small Business Economics 52: 523-43. [CrossRef]

Ghio, Niccolò, Massimiliano Guerini, Erik Lehmann, and Cristina Rossi-Lamastra. 2015. The emergence of the knowledge spillover theory of entrepreneurship. Small Business Economics 44: 1-18. [CrossRef]

Goetz, Stephan, and Anil Rupasingha. 2009. Determinants of growth in non-farm proprietor densities in the US, 1990-2000. Small Business Economics 32: 425-38. [CrossRef]

Gollwitzer, Peter, and Veronika Brandstätter. 1997. Implementation intentions and effective goal pursuit. Journal of Personality and Social Psychology 73: 186-99. [CrossRef]

Gomez-Mejia, Luis, and David Balkin. 1989. Effectiveness of individual and aggregate compensation strategies. Industrial Relations: A Journal of Economy and Society 28: 431-45. [CrossRef]

Grimaldi, Rosa, Martin Kenney, Donald Siegel, and Mike Wright. 2011. 30 years after Bayh-Dole: Reassessing academic entrepreneurship. Research Policy 40: 1045-57. [CrossRef]

Hair, Joseph, Rolph Anderson, Ronald Tatham, and William Black. 1995. Multivariate Data Analysis with Readings. Englewood Cliffs: Prentice-Hall.

Hayter, Christopher, Roman Lubynsky, and Spiro Maroulis. 2016. Who is the academic entrepreneur? The role of graduate students in the development of university spinoffs. The Journal of Technology Transfer 42: 1237-54. [CrossRef]

Honig, Benson. 2004. Entrepreneurship education: Toward a model of contingency-based business planning. Academy of Management Learning E Education 3: 258-73. [CrossRef]

Jansen, Slinger, Tommy Van De Zande, Sjaak Brinkkemper, Erik Stam, and Vasudeva Varma. 2015. How education, stimulation, and incubation encourage student entrepreneurship: Observations from MIT, IIIT, and Utrecht University. The International Journal of Management Education 13: 170-81. [CrossRef]

Kassean, Hermant, Jeff Vanevenhoven, Erik Liguori, and Doan Winkel. 2015. Entrepreneurship education: A need for reflection, real-world experience and action. International Journal of Entrepreneurial Behavior E Research 21: 690-708. [CrossRef]

Kolvereid, Lars, and Øystein Moen. 1997. Entrepreneurship among business graduates: Does a major in entrepreneurship make a difference? Journal of European Industrial Training 21: 154-60. [CrossRef]

Kraaijenbrink, Jeroen, Ger Bos, and Aard Groen. 2010. What do students think of the entrepreneurial support given by their universities? International Journal of Entrepreneurship and Small Business 9: 110-25. [CrossRef]

Krueger, Norris. 1993. The impact of prior entrepreneurship exposure on perception of new venture feasibility and desirability. Entrepreneurship Theory and Practice 18: 5-21. [CrossRef]

Krueger, Norris, and Carsrud Alan. 1993. Entrepreneurial intentions: Applying the theory of planned behaviour. Entrepreneurship $\mathcal{E}$ Regional Development 5: 315-30.

Krueger, Norris, Michael Reilly, and Alan Carsrud. 2000. Competing models of entrepreneurial intentions. Journal of Business Venturing 15: 411-32. [CrossRef] 
Krueger, Norris. 2009. Entrepreneurial intentions are dead: Long live entrepreneurial intentions. In Understanding the Entrepreneurial Mind. Edited by Alan Carsrud and Malin Brännback. New York: Springer, pp. 51-72.

Liñán, Francisco, and Alain Fayolle. 2015. A systematic literature review on entrepreneurial intentions: Citation, thematic analyses, and research agenda. International Entrepreneurship and Management Journal 11: 907-33. [CrossRef]

Low, Sarah, and Andrew Isserman. 2015. Where are the innovative entrepreneurs? Identifying innovative industries and measuring innovative entrepreneurship. International Regional Science Review 38: 171-201. [CrossRef]

Menzies, Teresa, and Joseph Paradi. 2002. Encouraging technology-based ventures: Entrepreneurship education and engineering graduates. New England Journal of Entrepreneurship 5: 57-64. [CrossRef]

Minola, Tommaso, Davide Donina, and Michele Meoli. 2016. Students climbing the entrepreneurial ladder: Does university internationalization pay off? Small Business Economics 47: 565-87. [CrossRef]

Morris, Michael, Galina Shirokova, and Tatyana Tsukanova. 2017. Student entrepreneurship and the university ecosystem: A multi-country empirical exploration. European Journal of International Management 11: 65-85. [CrossRef]

Mosey, Simon. 2016. Teaching and research opportunities in technology entrepreneurship. Technovation 57: 43-44. [CrossRef]

Mosey, Simon, Maribel Guerrero, and Andrew Greenman. 2017. Technology entrepreneurship research opportunities: Insights from across Europe. The Journal of Technology Transfer 42: 1-9. [CrossRef]

Nacu, Cosmin Mihai, and Silvia Avasilcăi. 2014. Technological ecopreneurship: Conceptual approaches. Procedia-Social and Behavioral Sciences 124: 229-35. [CrossRef]

National Statistical Institute. 2016. Education in the Republic of Bulgaria 2016. Sofia. Available online: https://nsi.bg/sites/default/ files / files / pressreleases/Education2016_en_DCRPGL6.pdf (accessed on 21 November 2020).

OECD. 2014. Innovate Reviews: Universities, Entrepreneurship and Local Development. Promoting Innovation and Entrepreneurial Mind-Sets Through Higher Education. Country-Level Review Bulgaria. Available online: https://www.oecd.org/cfe/leed/ OECD-LEED\$-\$2015-Bulgaria-report.pdf (accessed on 21 January 2019).

Onjewu, Adah-Kole E., Mohamed Yacine Haddoud, and Witold Nowiński. 2021. The effect of entrepreneurship education on nascent entrepreneurship. Industry and Higher Education 35: 09504222211014038. [CrossRef]

Orbell, Sheina, Sara Hodgldns, and Paschal Sheeran. 1997. Implementation intentions and the theory of planned behavior. Personality and Social Psychology Bulletin 23: 945-54. [CrossRef]

Petti, Claudio. 2009. Cases in Technological Entrepreneurship: Converting Ideas into Value. Northampton: Edward Elgar.

Pittaway, Luke, and Jason Cope. 2007. Simulating entrepreneurial learning: Integrating experiential and collaborative approaches to learning. Management Learning 38: 211-33. [CrossRef]

Rasmussen, Einar, and Roger Sørheim. 2006. Action-based entrepreneurship education. Technovation 26: 185-94. [CrossRef]

Ratinho, Tiago, Rainer Harms, and Steve Walsh. 2015. Structuring the Technology Entrepreneurship publication landscape: Making sense out of chaos. Technological Forecasting and Social Change 100: 168-75. [CrossRef]

Rauch, Andreas, and Willem Hulsink. 2015. Putting entrepreneurship education where the intention to act lies: An investigation into the impact of entrepreneurship education on entrepreneurial behavior. Academy of Management Learning E Education 14: 187-204. [CrossRef]

Rideout, Elaine, and Denis Gray. 2013. Does entrepreneurship education really work? A review and methodological critique of the empirical literature on the effects of university-based entrepreneurship education. Journal of Small Business Management 51: 329-51. [CrossRef]

Rupasingha, Anil, and Sergio Contreras. 2014. Factors Affecting Spatial Variation of Microenterprises in the Rural United States. American Journal of Entrepreneurship 7.

Sansone, Giuliano, Daniele Battaglia, Paolo Landoni, and Emilio Paolucci. 2021. Academic spinoffs: The role of entrepreneurship education. International Entrepreneurship and Management Journal 17: 369-99. [CrossRef]

Schlaegel, Christopher, and Michael Koenig. 2014. Determinants of entrepreneurial intent: A meta-analytic test and integration of competing models. Entrepreneurship Theory and Practice 38: 291-332. [CrossRef]

Secundo, Giustina, Gioconda Mele, Giuliano Sansone, and Emilio Paolucci. 2020. Entrepreneurship Education Centres in universities: Evidence and insights from Italian "Contamination Lab" cases. International Journal of Entrepreneurial Behaviour and Research 26: 1311-33. [CrossRef]

Shane, Scott, and Sankaran Venkataraman. 2003. Guest editors' introduction to the special issue on technology entrepreneurship. Research Policy 32: 181-84. [CrossRef]

Sheeran, Paschal, and Sheina Orbell. 1999. Implementation intentions and repeated behaviour: Augmenting the predictive validity of the theory of planned behaviour. European Journal of Social Psychology 29: 349-69. [CrossRef]

Shirokova, Galina, Oleksiy Osiyevskyy, and Karina Bogatyreva. 2016. Exploring the intention-behavior link in student entrepreneurship: Moderating effects of individual and environmental characteristics. European Management Journal 34: 386-99. [CrossRef]

Shook, Christopher, Richard Priem, and Jeffrey McGee. 2003. Venture creation and the enterprising individual: A review and synthesis. Journal of management 29: 379-99. [CrossRef]

Sieger, Philipp, Urs Fueglistaller, Thomas Zellweger, and Ilija Braun. 2018. Global Student Entrepreneurship 2018: Insights From 54 Countries. St. Gallen/Bern: KMU-HSG/IMU. In Global GUESSS Report 3. St. Gallen: University of St. Gallen. 
Souitaris, Vangelis, Stefania Zerbinati, and Andreas Al-Laham. 2007. Do entrepreneurship programmes raise entrepreneurial intention of science and engineering students? The effect of learning, inspiration and resources. Journal of Business Venturing 22: 566-91. [CrossRef]

Trivedi, Rohit. 2016. Does university play significant role in shaping entrepreneurial intention? A cross-country comparative analysis. Journal of Small Business and Enterprise Development 23: 790-811. [CrossRef]

Van Looy, Bart, Paolo Landoni, Julie Callaert, Bruno Van Pottelsberghe, Eleftherios Sapsalis, and Koenraad Debackere. 2011. Entrepreneurial effectiveness of European universities: An empirical assessment of antecedents and trade-offs. Research Policy 40: 553-64. [CrossRef]

Van Praag, Mirjam, and Peter Versloot. 2007. What is the value of entrepreneurship? A review of recent research. Small Business Economics 29: 351-82. [CrossRef]

Varela, Rodrigo, and Jorge Enrique Jiménez. 2001. The effect of entrepreneurship education in the universities of Cali. In Frontiers of Entrepreneurship Research, Babson Conference Proceedings. Available online: http:/ / www.babson.edu/entrep/fer (accessed on 21 January 2019).

Walter, Sascha, Praveen Parboteeah, and Achim Walter. 2013. University departments and self-employment intentions of business students: A cross-level analysis. Entrepreneurship Theory and Practice 37: 175-200. [CrossRef]

Wright, Mike, Donald Siegel, and Philippe Mustar. 2017. An emerging ecosystem for student start-ups. The Journal of Technology Transfer 42: 909-22. [CrossRef]

Wright, Mike, Philippe Mustar, and Donald Siegel. 2019. Student Start-Ups: The New Landscape of Academic Entrepreneurship. World Scientific Series on Public Policy and Technological Innovation; Singapore: World Scientific, vol. 1. [CrossRef]

Zhang, Gang, Xuebing Peng, and Jun Li. 2008. Technological entrepreneurship and policy environment: A case of China. Journal of Small Business and Enterprise Development 15: 733-51. [CrossRef] 